\title{
Constraints Faced by Farm Women in Participation in Agricultural Activities in Udaipur District of Rajasthan, India
}

\author{
Shanabanu H. Malek* and S.S. Sisodia
}

Department of Extension Education, MPUAT, Udaipur (Rajasthan), India

*Corresponding author

\section{Keywords}

Farm women, Participation, Agricultural activities, Constraints, WMS

Article Info

Accepted:

04 October 2019

Available Online:

10 November 2019

\section{A B S T R A C T}

\section{Introduction}

Women constitute almost half of the work force engaged in agriculture. Rural women constitute the most important productive work force in the Indian economy. In rural India, the percentage of women who depend on agriculture for their livelihood is as high as 84.00 per cent. Agriculture in India contributes about 18.00 per cent GDP and is predominantly a female activity. The rural women participate in a broad range of agricultural activities such as production, processing, preservation and utilization of food. They play a key role in the entire food system starting from the selection of seed, sowing, manuring, weeding, drying, stacking storing and feeding the family from the harvested produce. Further, they play a major in the decision making process at household level.

\section{Materials and Methods}

The present study was conducted in Udaipur district of Rajasthan State. For this study, two tehsils namely Girwa and Vallabhnagar were purposively selected on the basis of the maximum female population in the district, from each tehsil 5 villages were selected on the basis of maximum female population so, total 10 villages from both tehsils were selected and from each tehsil 10 respondents were randomly selected. Total 100 
respondents selected from villages, they were interviewed, personally to collect the data with the help of pre structured interview schedule. Thereafter, data were tabulated, analysed and inferences were drawn in light of the objective.

\section{Results and Discussion}

\section{Constraints faced by farm women in participation in agricultural activities}

Farm women were asked to mention their constraints faced in participation in agricultural activities. They were asked on three-point rating i.e., mostly, some times and never faced the constraints in participation in agricultural activities and accordingly scores were given as 2, 1, and 0, respectively. Mean score was calculated for each constraint to assign them rank. The data regarding the constraints faced by farm women in participation in agricultural activities are presented in Table 1.

The data presented in Table 1 reveal that farm women experienced some constraints at major level. These constraints were: "dual responsibility of work at farm and home work" ranked first and with weightage mean score 1.990 followed by "non availability of suitable farm implements and machinery for women" with rank second (WMS 1.896) and "lack of physical abilities" to carry out some agricultural works rank third (WMS 1.693).

Farm women faced the constraints on moderate level were i.e. "Difficulties in some agricultural work" with rank fourth and weightage mean score 1.669 followed by “social barriers"(WMS 1.527), "lack of interest to participate in agricultural work" (WMS 1.510), "lack of female extension workers for imparting training to women" (WMS 1.342), "lack of experience about agricultural works" (WMS 1.086) and "lack of extension contact" (WMS 0.692) with rank fifth, sixth, seventh, eighth and ninth, respectively.

The constraints which were less experienced by farm women were: lack of specific skill for agricultural works (WMS 0.667) rank tenth followed by "lack of knowledge about latest agricultural technology" within weightage mean score 0.523, "lack of land holding power" (WMS 0.357), and "lower consideration in decisions related to farming" (WMS 0.325) with rank eleventh, twelfth and thirteenth, respectively.

Out of 13 constraints identified in the participation in agricultural activities, the most important constraints faced by farm women were:

Dual responsibility of work at farm and home

Non availability of suitable farm implements and machinery for women

Difficulties in some agricultural works

Lack of physical abilities to carry out some agricultural works

Social barriers

Lack of interest to participate in agricultural works 
Table.1 Constraints faced by farm women in participation in agricultural activities

\begin{tabular}{|c|c|c|c|}
\hline Sr. No & Constraints & Mean Score & Rank \\
\hline 1 & Lack of experience about agricultural works & 1.086 & VIII \\
\hline 2 & $\begin{array}{l}\text { Non-availability of suitable farm implements and } \\
\text { machinery for women }\end{array}$ & 1.896 & II \\
\hline 3 & Social barriers & 1.527 & $\mathrm{~V}$ \\
\hline 4 & $\begin{array}{l}\text { Lack of physical abilities to carry out some } \\
\text { agricultural works }\end{array}$ & 1.693 & III \\
\hline 5 & $\begin{array}{l}\text { Lack of female extension workers for imparting } \\
\text { training to women }\end{array}$ & 1.342 & VII \\
\hline 6 & $\begin{array}{c}\text { Dual responsibility of work at farm and household } \\
\text { work }\end{array}$ & 1.990 & I \\
\hline 7 & Lack of interest to participate in agricultural work & 1.510 & VI \\
\hline 8 & Difficulties in some agricultural work & 1.669 & IV \\
\hline 9 & Lower consideration in decisions related to farming & 0.325 & XIII \\
\hline 10 & Lack of land holding power & 0.357 & XII \\
\hline 11 & Lack of extension contact & 0.692 & IX \\
\hline 12 & $\begin{array}{l}\text { Lack of knowledge about latest agricultural } \\
\text { technology }\end{array}$ & 0.523 & XI \\
\hline 13 & Lack of specific skill for agricultural works & 0.667 & $\mathrm{X}$ \\
\hline
\end{tabular}

\section{References}

Girade, S. and Shmbharkar,Y. 2012. Profile of farm women and constraints faced by them in Participation of farm and allied activities. Indian journal of applies research. 12(1): 69-71.

Gupta, S. 2016. Participation of rural women in agricultural and animal husbandry- A study. Bhartiya Krishi Anushandhan Patrika. 31(4): 314-317.

Gupta, S. 2016. Participation of rural women in agricultural and animal husbandry- A study. Bhartiya Krishi Anushandhan Patrika.31(4): 314-317.

Jahan, N. and Khan, N. 2016. To study the participation of farm women in various agriculture and allied activities.
International Journal of Home Science. 2(2): 180-186.

Saleh, R.A. and Shettima M.B. 2016. Analysis of women farmer's participation in agricultural activities in konduga local government area of Borno state, Nigeria. American Journal of Environmental Science. 16(1): 119-125.

Upadhyay, S., Desai, C.P. 2011. Participation of farm women in animal husbandry in Anand district of Gujarat. Journal of Community Mobilization and Sustainable Development. 6(2): 117-121. Vaghasiya., K.P. 2018. Pattern of participation of farm women in agricultural activities and decision making in Rajkot district of Gujarat state. M.Sc. (Agri) Thesis (Unpub), JAU, Junagadh.

\section{How to cite this article:}

Shanabanu H. Malek and Sisodia, S.S. 2019. Constraints Faced by Farm Women in Participation in Agricultural Activities in Udaipur District of Rajasthan, India. Int.J.Curr.Microbiol.App.Sci. 8(11): 140-142. doi: https://doi.org/10.20546/ijcmas.2019.811.017 